\title{
Edukasi tentang Keuntungan Menggunakan KB IUD di Kelurahan Bagan Pete Kota Jambi
}

\author{
Tuhu Perwitasari \\ Prodi D III Kebidanan STIKes Baiturrahim Jambi \\ Email:tuhuedie@ymail.com
}

Submitted : 17/03/2020

Accepted: 02/04/2020

Published: 16/06/2020

\begin{abstract}
The degree of health is influenced by many factors including the environment, behavior, health services and heredity. health is a basic human right and is one of the factors that determine the quality of human resources. The use of contraception is an effort to maintain health. there are various kinds of contraception one of which is the IUD. Intrauterine device (IUD) or also called an intrauterine device (IUD) is a very effective method of contraception to prevent pregnancy reaching 99.7\%. IUD birth control has many advantages including a long effective period of contraception that is 3-5 years, no hassle to remember the medication schedule, no need to change devices, or refill prescriptions and return to the doctor or midwifeto repeat contraception and most importantly the return of fertility can occur immediately after removing the IUD. These advantages make IUD birth control a pregnancy delay tool that is most effective compared to other contraceptives. the lack of mother's knowledge about the benefits of using the IUD birth control program and the large amount of incorrect information makes mothers reluctant to use the IUD birth control program. Current conditions, the use of effective long-term contraceptive methods, especially the IUD, has relatively decreased while the use of hormonal contraceptive methods dominates. the provision of information through counseling is aimed at women of childbearing age and pregnant women so that they can provide appropriate information about the benefits of using $K B I U D s$ and the awareness of mothers to use safer contraception andlong-term. long-range
\end{abstract}

Keywords: education, health, KB IUD

\begin{abstract}
Abstrak
Derajat kesehatan dipengaruhi banyak faktor antara lain lingkungan, perilaku, pelayanan kesehatan dan keturunan. Kesehatan merupakan hak dasar yang dimiliki manusia dan merupakan salah satu faktor yang sangat menentukan kualitas Sumber Daya Manusia. Penggunaan kontrasepsi merupakan salah satu upaya menjaga kesehatan. Terdapat berbagai macam kontrasepsi salah satunya adalah IUD. Intrauterine device (IUD) atau disebut juga dengan alat kontrasepsi dalam rahim (AKDR) merupakan metode kontrasepsi yang sangat efektif untuk mencegah kehamilan mencapai 99,7\%. Pemasangan KB IUD memiliki banyak keuntungan antara lain jangka waktu efektif kontrasepsi yang panjang yaitu 3-5 tahun, tidak repot mengingat jadwal minum obat, tidak perlu gonta-ganti alat, atau isi ulang resep dan kembali ke dokter atau bidan untuk mengulang kontrasepsi dan yang paling utama kembalinya kesuburan dapat segera terjadi setelah melepas IUD. Keunggulannya ini membuat KB IUD menjadi alat penunda kehamilan yang paling efektif dibandingkan alat kontrasepsi lainnya. Masih kurangnya pengetahuan ibu tentang keuntungan menggunakan KB IUD dan banyaknya informasi yang salah membuat ibu enggan menggunakan KB IUD. Kondisi saat ini, pemakaian metode kontrasepi efektif jangka panjang khususnya IUD relatif mengalami penurunan sedangkan penggunaan metode kontrasepsi hormonal mendominasi. Pemberian informasi melalui penyuluhan ini ditujukan pada wanita usia subur dan ibu hamil sehingga dapat memberikan informasi yang tepat tentang keuntungan menggunakan KB IUD serta kesadaran ibu untuk menggunakan kontrasepsi yang lebih aman dan jangka panjang.
\end{abstract}

Kata Kunci: edukasi, KB IUD, kesehatan 


\section{PENDAHULUAN}

Program keluarga berencana $(\mathrm{KB})$ adalah salah satu upaya pemerintah untuk mengendalikan peningkatan pertumbuhan penduduk. Tujuan program KB adalah: mengatur kehamilan, kesehatan reproduksi yang berkualitas, menurunkan tingkat atau angka kematian ibu, bayi dan anak, serta penanggulangan masalah kesehatan reproduksi dalam rangka membangun keluarga kecil berkualitas.

Pengetahuan akseptor KB tentang pemakaian alat kontrasepsi memegang peranan penting dalam menentukan sikap dalam pemilihan kontrasepsi. Akseptor KB harus mengenal dan memahami tentang pengertian, jenis kontrasepsi, keuntungan, cara pemakaian, efek samping dan kontraindikasi dalam pemakaian alat kontrasepsi. Pengetahuan dan sikap merupakan domain penting untuk pembentukan tindakan atau perilaku. Perilaku yang didasari oleh pengetahuan dan sikap positif akan berlangsung lama.

Sikap dan pandangan negatif yang beredar dimasyarakat berkaitan dengan pengetahuan dan pendidikan seseorang. Banyak mitos tentang IUD seperti mudah terlepas jika bekerja terlalu keras, menimbulkan kemandulan dan lain sebagainya. Bidan mempunyai peran dalam meningkatkan tingkat pemakaian $\mathrm{KB}$ sebagai tindakan preventif terutama bagi wanita dengan resiko. Pendidikan/konseling KB yang dilakukan oleh bidan akan signifikan dalam mengunggah kesadaran masyarakat untuk ber-KB. Hasil Survei Demografi dan Kesehatan Indonesia (SDKI) 2012 mengumumkan bahwa, total jumlah penduduk Indonesia kini mencapai 240 juta dan 10 provinsi di Indonesia menjadi penyumbang 70 persen dari total penduduk.

Faktor keputusan akseptor KB untuk menggunakan alat kontrasepsi IUD tidak terlepas dari faktor perilaku yang dimiliki oleh masing-masing individu. Adapun faktor-faktor yang merupakan penyebab perilaku memilih alat kontrasepsi IUD dapat dijelaskan dengan menurut Notoatmodjo (2003) yang dibedakan dalam tiga jenis yaitu: faktor predisposisi (umur, pengetahuan, jumlah anak), faktor pendukung (keamanan alat kontrasepsi IUD, ketersediaan alat kontrasepsi IUD, tempat pelayanan), faktor pendorong (petugas kesehatan, media informasi, biaya pemasangan, dukungan suami).

Rendahnya pengguna kontrasepsi IUD disebabkan oleh kurangnya informasi tentang manfaat menggunakan kontrasepsi IUD sehingga sikap ibu dalam pemilihan IUD masih sangat rendah yang berdampak pada tindakan dalam pemilihan kontrasepsi IUD. Keadaan tersebut sangat mempengaruhi keputusan ibu untuk menggunakan kontrasepsi IUD.

Berdasarkan alasan diatas maka masyarakat terutama wanita usia subur di Kelurahan Bagan Pete perlu dibentuk organisasi yang dapat menampung permasalahan yang berkaitan dengan kebutuhan wanita usia subur, salah satunya dengan kegiatan penyuluhan. Kegiatan ini sebagai wadah menampung permasalahan dan tempat bertanya tentang bagaimana menyiapkan kehamilan, persalinan, nifas, perawatan bayi yang sehat dan persiapan kontrasepsi.

\section{TARGET DAN LUARAN}

Target dalam kegiatan pengabdian kepada masyarakat ini adalah memberikan penyuluhan kesehatan tentang Edukasi Keuntungan Menggunakan KB IUD Di Kelurahan Bagan Pete kepada wanita usia subur dan ibu hamil. Adapun luaran dalam kegiatan pengabdian kepada ini adalah publikasi pada jurnal ilmiah dan meningkatkan kesadaran ibu usia subur dan ibu hamil dengan harapan dapat memberikan pengetahuan mengenai apa saja keuntungan menggunakan KB IUD. 


\section{METODE PELAKSANAAN}

Pengabdian kepada masyarakat ini dilaksanakan pada bulan Februari 2019 di kelompok yasinan di Kelurahan Bagan Pete. Sasaran kegiatan ini adalah wanita usia subur dan ibu hamil yang ada di kelompok yasinan.

Kegiatan pengabdian kepada masyarakat ini, mendapat rekomendasi dari Kepala Kelurahan Bagan Pete dan Kader setempat untuk memberikan informasi tentang keuntungan menggunakan KB IUD melalui penyuluhan kepada wanita usia subur dan ibu hamil yang ada di kelompok yasinan. Metode yang digunakan dalam penyuluhan ini adalah ceramah, diskusi dan tanya jawab menggunakan media power point.

Tahapan kegiatan pengabdian kepada masyarakat meliputi:

1. Mengkaji dan menganalisis data

2. Mengidentifikasi masalah

3. Menyusun rencana kegiatan

4. Menyusun SAP, materi, instrumen prepost test serta membuat power point

5. Mengurus izin lokasi kegiatan

6. Melakukan pretest

7. Melakukan penyuluhan tentang keuntungan menggunakan KB IUD menggunakan power point sesuai SAP yang telah disusun

8. Melakukan post test

9. Melakukan monitoring dan evaluasi

\section{HASIL DAN PEMBAHASAN}

Pelaksanaan kegiatan pengabdian kepada masyarakat berjalan sesuai dengan rencana yang disusun. Kegiatan ini dilaksanakan kepada $30 \mathrm{ibu}$ yang menghadiri kegiatan yasinan. Dalam pelaksanaan kegiatan ini Tim dibantu oleh mahasiswa, bidan desa dan kader yang sedang bertugas di kelurahan bagan pete.

Sebelum dilakukan penyuluhan tentang keuntungan menggunakan KB IUD tim melakukan pretest. Hasilnya hanya $40 \%$ ibu mampu menjelaskan pengertian KB IUD, $35 \%$ ibu mampu menyebutkan tujuan menggunakan KB IUD, 25\% ibu mampu menguraikan kelebihan menggunakan $\mathrm{KB}$ IUD, 65\% ibu mampu menyebutkan tempat pemasangan $\mathrm{KB}$ IUD, $40 \%$ ibu mampu menyebutkan jadwal kontrol KB IUD, $45 \%$ ibu mampu menerangkan keadaan yang tidak memperbolehkan menggunakan KB IUD, dan $45 \%$ ibu mampu menerangkan efek samping setelah menggunakan $\mathrm{KB}$ IUD.

Penyuluhan dalam pengabdian kepada masyarakat ini dilakukan dengan metode ceramah untuk menjelaskan ide, pengertian secara lisan disertai dengan diskusi dan tanya jawab sehingga wanita usia subur dan ibu hamil memahami apa yang diberikan dan disampaikan. Selain itu, materi yang diberikan ditampilkan melalui media power point yang berisi informasi penting tentang keuntungan menggunakan KB IUD yang disertai gambar-gambar menarik sehingga ibu mudah menangkap informasi yang diberikan. Selama proses penyuluhan berlangsung ibu-ibu sangat antusias mendengarkan sambil memberikan tanggapan baik dalam diskusi, 70\% ibu bertanya terkait dengan materi yang disampaikan.

Setelah diberikan informasi tentang keuntungan menggunakan KB IUD tim melakukan posttest. Hasilnya mengalami peningkatan yaitu sebanyak $80 \%$ ibu dapat menjelaskan pengertian KB IUD, $75 \%$ ibu mampu menyebutkan tujuan menggunakan KB IUD, 78\% ibu mampu menguraikan kelebihan menggunakan KB IUD, 85\% ibu mampu menyebutkan tempat pemasangan KB IUD, 90\% ibu mampu menyebutkan jadwal kontrol KB IUD, 85\% ibu mampu menerangkan keadaan yang tidak memperbolehkan menggunakan KB IUD, dan $85 \%$ ibu mampu menerangkan efek samping setelah menggunakan KB IUD. 


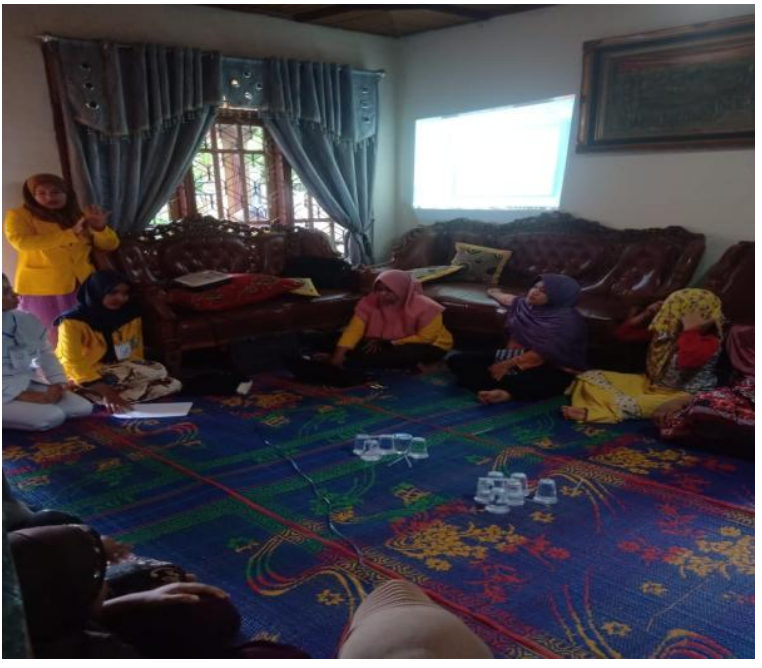

Gambar.1 Kegiatan Pengabdian

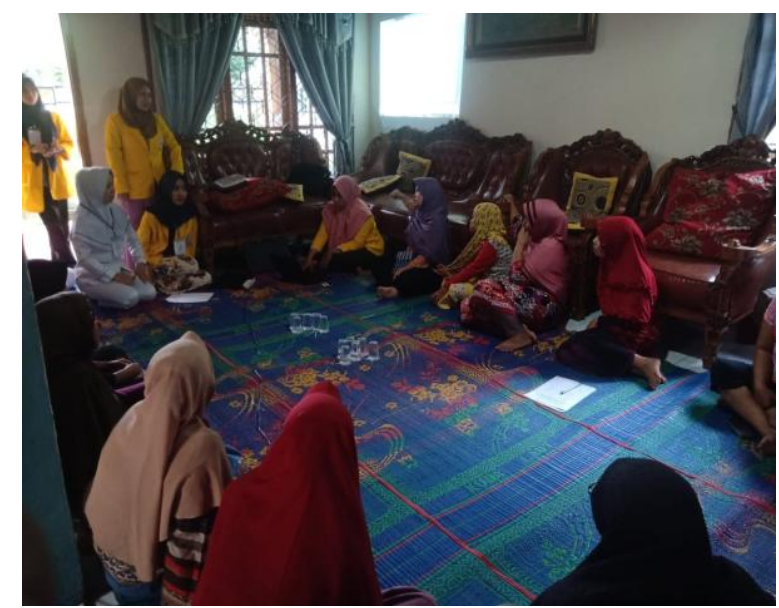

Gambar.2 Kegiatan Pengabdian

Hasil ini sejalan dengan penelitian yang dilakukan oleh Saidah dan sari, dinyatakan bahwa terdapat pengaruh konseling terhadap tingkat kecemasan pada aseptor KB IUD post plasenta dengan $p$ value $0,000<0,05$. Salah satu faktor yang memengaruhi pengetahuan adalah karena kekurangan informasi. Banyak yang kurang memahami tentang keuntungan menggunakan KB IUD, ketakutan akan efeksamping menggunakan KB IUD dan adanya persepsi salah yang beredar di masyarakat tentang penggunaan KB IUD. Prmosi kesehatan dapat Pemberian informasi melalui pendidikan dan pelatihan untuk meningkatkan pengetahuan, selanjutnya akan menimbulkan kesadaran dan akhirnya ibu akan melakukan praktek sesuai dengan pengetahuan yang dimiliki, meskipun memerlukan waktu yang tidak sebentar dan harus berulang.

Hasil penelitian serupa dilakukan oleh Veronica, dinyatakan ada hubungan pengetahuan dengan pemakaian KB IUD dengan nilai $\mathrm{p}=0,003<0,05$. Pengetahuan kurang baik memiliki peluang besar untuk tidak menggunakan KB IUD dibandingkan dengan ib yang memiliki pengetahuan yang baik. Salah satu strategi untuk memperoleh perubahan pengetahuan adalah dengan pemberian informasi untuk meningkatkan pengetahuan sehingga menimbulkan kesadaran dan dapat dilakukan dengan cara pemberian penyuluhan kesehatan.

Penelitian yang dilakukan oleh Purwaningrum, juga menunjukkan efeksamping KB IUD tidak ada hubungan yang signifikan dengan kelangsungan penggunaan IUD di Wilayah Kerja Puskesmas Waringin. Untuk meningkatkan target program pemerintah diharapkan lebih meningkatkan penyuluhan tentang keuntungan menggunakan KB IUD disertai efeksamping penggunaan sehingga masyarakat tahu dan paham mengenai $\mathrm{KB}$ IUD sehingga tercapainya program $\mathrm{KB}$ terutama KB IUD.

\section{KESIMPULAN DAN SARAN}

\section{Kesimpulan}

Pelaksanaan kegiatan pengabdian kepada masyarakat yang dilakukan melalui penyuluhan tentang keuntungan menggunakan KB IUD kepada ibu-ibu usia subur dan ibu hamil di kelompok yasinan Kelurahan Bagan Pete mampu meningkatkan pengetahuan dan kesadaran ibu untuk menggunakan KB jangka panjang agar dapat meningkatkan kesehatan terutama kesehatan organ reproduksi.

\section{Saran}

Disarankan kepada instansi yang terkait lebih mengoptimalkan peran tenaga kesehatan dalam memberikan penyuluhan 
secara rutin khususnya tentang penggunaan kontrasepsi jangka panjang seperti IUD sehingga ibu-ibu usia subur dan ibu hamil lebih mengetahui dan mau menggunakan KB IUD tanpa mengkhawatirkan efek samping.

\section{UCAPAN TERIMAKASIH}

Tim pengabdian masyarakat mengucapkan terima kasih yang sebesarbesarnya kepada STIKes Baiturrahim Jambi atas bantuan dana dan fasilitas surat izin. Serta Kepala Kelurahan Bagan Pete, Puskesmas Kenali Besar, Bidan Desa, Kader dan ibu-ibu setempat yang telah memfasilitasi dan memberikan izin sebagai tempat pengabdian kepada masyrakat ini, sehingga kegiatan pengabdian masyarakat ini dapat berjalan dengan lancar sesuai dengan waktu yang telah ditentukan.

\section{DAFTAR PUSTAKA}

Fitriani, S. 2013. Promosi Kesehatan. Graha Ilmu. Yogyakarta.

Kementerian Kesehatan RI. 2016. Profil Kesehatan Indonesia 2015. Kesehatan Kementerian Kesehatan RI. Jakarta.

Kementrian Kesehatan RI. 2013. Riset Kesehatan Dasar 2013. Badan Penelitian dan Pengembangan Kesehatan Kementrian Kesehatan RI.

Purwaningrum, Y. Efek Samping KB IUD (Nyeri Perut) dengan Kelangsungan Penggunaan KB IUD. Jurnal Kesehatan. 2017:5.1:2354-5852.

Saidah H, Sari DK. Pengaruh Konseling Terhadap Tingkat Kecemasan Aseptor KB IUD Post Plasenta Di Rsud Kota Madiun Tahun 2019. Jurnal Kebidanan.2019;8.1:23023082.

Veronica SY, Safitri R, Rohani R. FaktorFaktor yang Berhubungan dengan Pemakaian KB IUD pada Wanita Usia Subur. Wellness and Healthy Magazine. 2019:1(2):223-230. 